\title{
The 2008 recipient of the Brady Medal: Professor Katharina von Salis
}

\author{
DANIELA N. SCHMIDT ${ }^{1, *}$, JEREMY R. YOUNG $^{2}$, SHIRLEY VAN HECK $^{3}$ \& JACKIE LEES \\ ${ }^{1}$ Department of Earth Sciences, University of Bristol, Bristol BS8 1RJ, UK \\ ${ }^{2}$ Palaeontology Department, The Natural History Museum, London SW7 5BD, UK \\ ${ }^{3}$ Shell International Exploration and Production B.V., Kessler Park 1, 2288GS Rijswijk, The Netherlands \\ ${ }^{4}$ Department of Earth Sciences, University College London, London WC1E 6BT, UK \\ ${ }^{*}$ Corresponding author (e-mail: d.schmidt@bristol.ac.uk)
}

\section{INTRODUCTION}

The Brady Medal, the highest award of The Micropalaeontological Society, is given to scientists who have had a major influence on micropalaeontology by means of a substantial body of excellent research and additionally service to the scientific community. It is named in honour of the brothers George and Henry Brady, pioneers of foraminiferal and ostracod research, respectively, both of whose work included landmark studies of material from the Challenger expedition. If the Challenger revolutionized nineteenth century oceanography, then the Glomar Challenger and the Deep Sea Drilling Project (DSDP) did the same for twentieth century micropalaeontology and palaeoceanography. So, it is fitting that the second Brady medal should go to one of the great contributors to DSDP microfossil studies, Katharina von Salis Perch-Nielsen.

To use the words of her mother, Katharina is "curious, logical, inventive and rebellious, with an extreme sense for justice'. As a researcher, she made outstanding contributions to nannofossil taxonomy, biostratigraphy and palaeobiology. She both carried out an immense body of primary research and synthesized her encyclopaedic knowledge of nannofossils in a series of seminal syntheses, which have provided the basis for subsequent research. Moreover, she played a unique role in encouraging, supporting and facilitating micropalaeontological research and researchers.

\section{EARLY STUDIES}

Katharina was born in 1940 in Zurich, and was brought up there and in Soglio in Graubünden, a high-Alpine municipality in southeastern Switzerland, and commune of origin of the distinguished von Salis family. Her own branch of the family was characterized by strong women - her grandmother was a famous painter, mountaineer and a single mother. Her mother is a well-known journalist.

She studied Geology at the University of Berne, mixing academic study with a formidable sporting career. In six years she completed both her undergraduate studies and a $\mathrm{PhD}$ on the geology and sedimentology of the molasse. In parallel, Katharina was Swiss Cross Country Skiing Champion from 1961 to 1965 , vice world champion in orienteering in 1966, and made a number of climbing first-ascents. Although she was also a keen climber, she was not allowed to join the exclusively male 'Alpenclub' of Berne University, which ironically had been founded by her grandfather, or to participate in their Svalbard expedition in 1960. So, it is perhaps not surprising that equal opportunity issues have always been very close to Katharina's heart.

After meeting Jørgen Perch-Nielsen at an international orienteering event, she moved in 1965 to Copenhagen where she carried out post-doctoral research on Eocene and Maastrichtian nannofossils from Denmark. She then moved to Paris in 1967 for further post-doctoral research on nannofossils.

In her post-doctoral research, she applied the difficult carbon-replication method for TEM study of nannofossils with great success, carrying out pioneering research on their structure and taxonomy, resulting in a string of publications, including two major monographs: 'Der Feinbau und die Klassifikation der Coccolithen aus dem Maastrichtien von Dänemark' [The structure and classification of coccoliths from the Maastrichtian of Denmark] and 'Elektronenmikroskopische Untersuchungen an Coccolithen und verwandten Formen aus dem Eozän von Dänemark' [Electronmicroscopic research of coccoliths and related forms from the Eocene of Denmark], both published in Biologiske Skrifter Kongelige Danske Videnskabernes Selskab (Perch-Nielson, 1968, 1971).

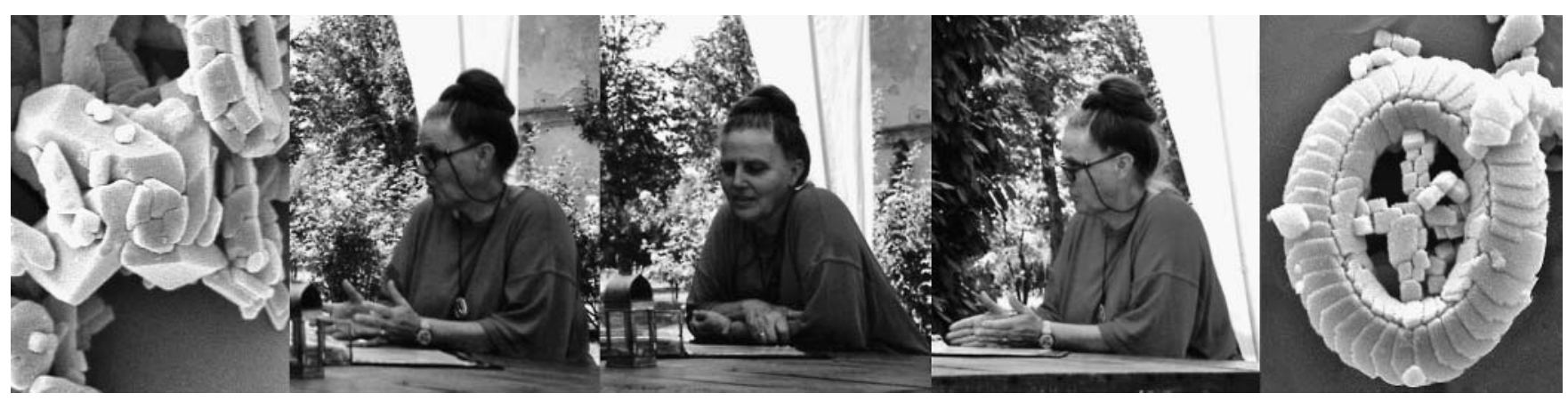

Fig. 1. Katharina in typical discursive mode, Chateau de Blagnac France September 1999, flanked by two of the many species she described: Micula prinsii and Cruciplacolithus primus, markers for the latest Maastrichtian and earliest Danian, respectively. 


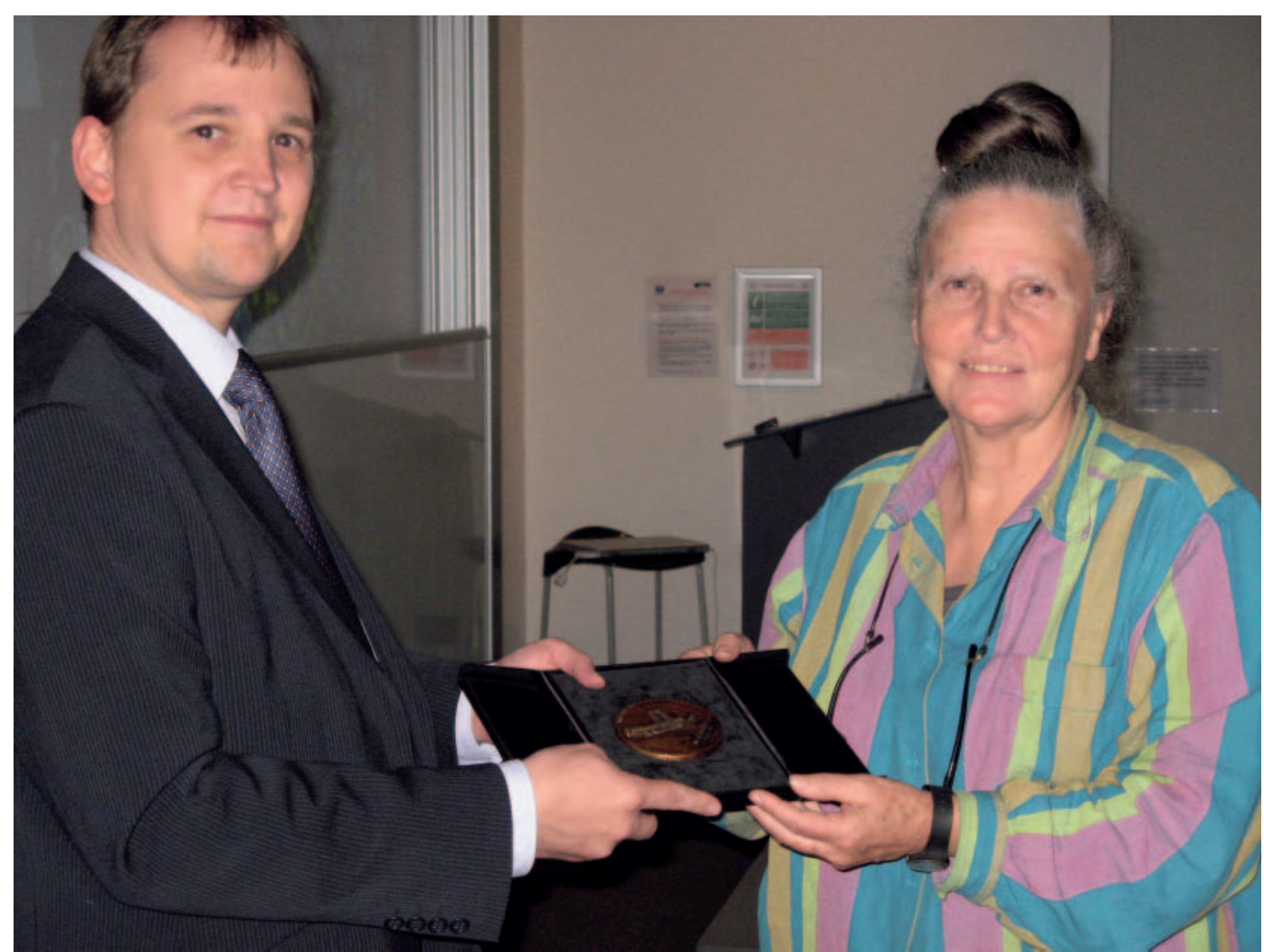

Fig. 2. The President of The Micropalaeontological Society Professor Michal Kucera presents the Brady medal to the 2008 recipient Professor Katharina von Salis.

\section{LECTURER COPENHAGEN 1968-74}

On the strength of this work, she was appointed lecturer at the University of Copenhagen in 1968 and worked there for seven immensely productive years. During her time in Denmark, she carried out intensive research on Cretaceous and Cenozoic nannofossil biostratigraphy and taxonomy, including participation on DSDP Legs 12 (1972), 29 (1973) and 39 (1974, co-chief scientist). This work culminated in probably the most important micropalaeontology paper published in a DSPD/ODP volume 'Albian to Pleistocene calcareous nannofossils from the Western South Atlantic, DSDP Leg 39' (Perch-Nielsen, 1977). In parallel, she started studying nannofossils from Cretaceous/Tertiary boundary sections from around the world, playing a leading role in the rapidly developing field of $\mathrm{K} / \mathrm{T}$ boundary research, and particularly in establishing the pattern of extinctions, survivorship and recovery of nannofossils in response to the event. She also participated fully in departmental work and was head of the Institute for Historical Geology and Palaeontology in 1973/74. Remarkably, she also became the first female geologist to work in Greenland, participating in, and latterly leading, three major expeditions there.

\section{PERIPATETIC PHASE 1974-89}

In 1974, the Perch-Nielsens began a peripatetic life as Jørgen's work as a senior executive of Shell took them round Europe. Initially they returned to Switzerland, where Katharina was appointed Oberassistentin at the Geological Institute at ETH Zurich and shortly after had the first of three daughters Nina,
Christina and Sabine. The family subsequently moved to Amsterdam, Vienna, The Hague and London, before finally returning to Zurich in 1989. During this period, Katharina held visiting appointments in the Free University Amsterdam and the Naturhistorisches Museum Vienna and worked extensively for Shell as a consultant biostratigrapher. Despite her family commitments, consultancy work and the lack of a permanent base or faculty position, Katharina maintained a high level of research activity. The Leg 39 studies were written up on a heroic scale in the Initial Reports volume she is first author on the seven site reports and four other chapters, totalling nearly 600 pages. Her $\mathrm{K} / \mathrm{T}$ boundary research continued with studies of sections from across the world, culminating in the epic 'Calcareous nannofossils from the Cretaceous between the North Sea and the Mediterranean' (Perch-Nielsen, 1979), a ground-breaking synthesis of nannofossil phylogeny, also including major development of Sissingh's CC nannofossil zonation scheme, greatly increasing its biostratigraphic utility. She followed this with her contributions to the seminal Bolli et al. (1985) Plankton Stratigraphy volume. She co-edited this volume, arguably the most important twentieth century publication on micropalaeontology, and wrote both the Mesozoic and Cenozoic syntheses of nannofossil taxonomy and the silicoflagellate chapter. These remain indispensable overviews of nannofossil taxonomy, classification and biostratigraphy, in daily use across the world.

As a great networker, Katharina also played a leading role in the micropalaeontological community. She proposed the formation of the International Nannoplankton Association (INA), 
was one of the founding members, its first president (1977-93) and the organizer of its first major meeting, in Vienna in 1985. She also organized or co-organized numerous other symposia and meetings on calcareous nannofossils (e.g. 1970 Rome, 1974 Kiel, 1979 Orléans, 1983 Copenhagen, and 1986 Zurich). As the leading nannofossil worker of her generation, Katharina was also called upon to referee hundreds of journal articles and DSDP and ODP chapters, typically combining detailed technical correction and sympathetic encouragement for publication of the key data. She still serves on the editorial board of Marine Micropaleontology, Bulletin de la Société géologique de France, Rivista Italiana di Paleontologia e Stratigrafia and Revue de Micropaléontologie.

\section{9-2001 ETH-ZURICH}

In 1989, Jørgen was appointed Chief Executive Officer of Shell Switzerland, so the family returned to Zurich. Katharina was appointed Titular Professor of Geology at the ETH. Her long-term interest in supporting women in science led to her being given a formal role in promoting equality of opportunity for women in technology and science at Swiss universities and high schools, in general, and at ETH Zurich, in particular, which led to the establishment of an Equal Opportunity office at ETH in 1993. She later carried on with this 'mission' at an international level. It also explains her name change. In 1990, the requirement under Swiss law that married women had to use their husband's name was finally changed. Having campaigned for this liberalization, Katharina felt she should use it, not least since reverting to von Salis would confuse bibliographers.

Despite this new focus she continued to undertake an impressive range of geological work. Notably, she played a major role in the NEPTUNE project of ETH, which synthesized tens of thousands of microfossil occurrence records from the DSDP and ODP into one, much-used, database. Katharina singlehandedly undertook the taxonomic cleaning and synonymizing of the nannofossil data. She also served as president of the Swiss committee of the International Geological Correlation Program, from 1993 to 2001. These commitments did somewhat reduce her personal research output, but she remained very active, publishing papers with numerous collaborators.

Since 'retiring' in 2001, the Perch-Nielsens have lived mostly in Katharina's home region of the Engadine. Here Katharina has redirected her remarkable energy to local community service, from serving on the local transport planning board to helping found the Engadine/St Moritz Alpenakadamie and GEOPARC and, more recently, to being elected to the regional parliament (following in her grandfather's footsteps). In her spare time, she conducts personal research into the archaeology of the Engadine, being in the habit of alerting the professionals to her finds, which include a 7000-year-old hearth at $2400 \mathrm{~m}$. She also regularly contributes articles and photographs to her local newspaper and, this summer, conducted the first walk through her home village for tourists.
The micropalaeontological community was fortunate that, for 35 years, Katharina devoted so much of her energy to our science. Through c. 150 papers, she played a critical role in developing nannofossil research, documenting nannofloral development and rationalizing nannofossil taxonomy, including the description of over 100 species. Perhaps, equally importantly, in a service with little recognition, Katharina von Salis has helped countless young scientists to develop their professional careers. She taught nannofossil taxonomy and stratigraphy to scores of students and guests over the years, and has acted as mentor and informal supervisor to numerous students. She loved meeting scientists, shared her knowledge and expertise freely with everyone and was always available for intensive discussions and manuscript reviews. She was also willing to go well beyond the conventional in her support for science, from getting her friends to help assemble the INA Newsletter, to hosting scientists she had never met to enable them to attend a conference. Every graduate of the ETH micropalaeontology group, as well as nannofossil researchers on every continent, have benefited from her scientific insight, wisdom and unselfish encouragement.

\section{AWARDS}

In 1988, Katharina was elected member of the Royal Academy of Science of Denmark and was awarded the Steno Medal of the Geological Society of Denmark, for her studies of the micropalaeontology and geology of Denmark and Greenland. In 2003, she was awarded Honorary Membership of the International Nannoplankton Association and, in 2007, the Prize by the Dr Ida Somazzi Foundation for her work in geology and equal opportunity. In awarding her the Brady Medal, The Micropalaeontology Society is proud to acknowledge our respect for her unique contributions to developing our science and enhancing our lives.

\section{Manuscript received 30 September 2008 Manuscript accepted 2 February 2009}

\section{REFERENCES}

Bolli, H.M., Saunders, J.B. \& Perch-Nielsen, K. 1985. Plankton stratigraphy. Cambridge University Press, Cambridge, 1032.

Perch-Nielsen, K. 1968. Der Feinbau und die Klassifikation der Coccolithen aus dem Maastrichtien von Danemark. Biologiske Skrifter. Kongelige Danske Videnskabernes Selskab 16, 1-96.

Perch-Nielsen, K. 1971. Elektronenmikroskopische untersuchungen an Coccolithen und verwandten Formen aus dem Eozan von Danemark. Biologiske Skrifter. Kongelige Danske Videnskabernes Selskab 18, $1-76$.

Perch-Nielsen, K. 1977. Albian to Pleistocene calcareous nannofossils from the Western South Atlantic, DSDP Leg 39. Deep Sea Drilling Project. Initial Reports; 39, 699-823.

Perch-Nielsen, K. 1979. Calcareous nannofossils from the Cretaceous between the North Sea and the Mediterranean. Aspekte der Kreide Europas, IUGS Series A 6, 223-272. 